\title{
Agronomic evaluation of green biodegradable mulch on melon crop
}

\author{
Ferruccio Filippi, ${ }^{1}$ Galileo Magnani, ${ }^{1}$ Sara Guerrini, ${ }^{2}$ Floriana Ranghino ${ }^{2}$ \\ ${ }^{1}$ Dipartimento di Biologia delle Piante Agrarie, Università di Pisa; ${ }^{2}$ Novamont S.p.A., Novara, Italy
}

\begin{abstract}
A two-year research was carried out in 2004-2005 in order to evaluate the effects of biodegradable green mulch on melon (Cucumis melo L. var. reticulatus Naud.) yield and quality. The loss of quality due to the presence of spot caused by the residues of biodegradable plastics was also investigated. The research was conducted over two years, in open field, at S. Piero a Grado, Pisa, Italy, (lat. 43.67498, long. 10.34737), from the beginning of May to the end of July of each year. The films tested in the first year experiment were two biodegradable ones with different colours (black and green) compared with a lowdensity polyethylene (LDPE) film, while in 2005 three biodegradable films, (two green and one black) were compared with a traditional LDPE film. The two green biodegradable films had different properties related to the biodegradation rate, faster in film $C v 205$, because of a different degree of Mater Bi polymer inside the film. In each year a randomized block design with four replications was followed.

Green biodegradable films allowed obtaining a higher yield than LDPE films maybe because of the higher soil temperatures reached, and excellent fruit quality, especially for the soluble solids content and the ripening process. At the same time, the presence of residues on the fruit skin was rather low because of the degradation of films occurred at the ripening time. In the first year, the percentage of spotted fruits was low for every kind of film, while in the second one the green film showed a higher presence of residues on skin compared with the black one. The biodegradable materials covered the soil for the whole crop cycle with a good mulching effect, and the successive degradation allowed to avoid the removal and disposal of plastic film, with a certain economic advantage.
\end{abstract}

Correspondence: Ferruccio Filippi, Dipartimento di Biologia delle Piante Agrarie, Università di Pisa, via del Borghetto 80, 56124 Pisa, Italy.

Tel. +39.050 .2216500 - Fax: +39.050 .2216524 .

E-mail: fefilippi@agr.unipi.it

Key words: vegetables, yield, quality, soil temperature, film properties.

Acknowledgements: this work conducted in the context of a Research Contract between the Department of Crop Biology, University of Pisa and the Novamont SpA Company (Novara, Italy).

Received for publication: 24 September 2010.

Accepted for publication: 26 March 2011.

(C) Copyright F. Filippi et al., 2011

Licensee PAGEPress, Italy

Italian Journal of Agronomy 2011; 6:e18

doi:10.4081/ija.2011.e18

This article is distributed under the terms of the Creative Commons Attribution Noncommercial License (by-nc 3.0) which permits any noncommercial use, distribution, and reproduction in any medium, provided the original author(s) and source are credited.

\section{Introduction}

The development of the degradable polymers has been one of the first attempt to solve the problem of the disposal of the plastics used for mulching. The first experiences regarded the use of naturally degradable materials, such as paper or vegetal fibres, already used in the past, or the mix between low-density polyethylene (LDPE) and compounds degraded by the soil microorganisms. However, both of these solutions did not guarantee acceptable agronomic results. Another step was the development of photodegradable materials with variable duration, according to different climate zones in which they were used. Even these materials were unsuitable because of the permanence of waste plastics in the soil at the end of the crop cycle (Boldrin, 1989; Brault et al., 2002; Davies et al., 1993; Mazollier, 2001; Olsen et al., 2001; Quezada Rosano et al., 1994; Vidril, 2001). The research was then directed towards the development of new totally degradable polymers (Mazollier, 2001), with which whereby it's possible to get film showing a different responsiveness in relation to their nature, their physical and mechanical characteristics and to different kind of degradation process.

Among these new biodegradable films for mulching, certainly the best interest concerns those prepared with a thermoplastic material containing starch (bearing the mark Mater-Bi, of Novamont S.p.A., Novara, Italy), which properties are similar to the traditional synthetic polymers based on polyethylene. This innovative material, in its process of degradation, is transformed by soil microorganisms into carbon dioxide, water and natural gas without the formation of compounds in any way toxic or harmful to the environment, as it has been highlighted through appropriate methodologies of analysis (Bastioli $e t$ al., 1999; Flechaire, 1991; Degli Innocenti et al., 2000). In particular, they are complying with the biodegradability European (EN 13432, 2000) and Italian (UNI 10785, 1999) regulations. Furthermore, these materials are approved for use in organic farming by the Italian Association of Organic Agriculture (AIAB), part of the International Federation of Organic Agriculture Movements (IFOAM).

The response of agronomic Mater-Bi biodegradable films for mulching has been studied for many years. The researchers focused their attention on the use of these materials under shelter or in open fields to check their behaviour on many vegetables (Candido et al., 2003; Caruso 1997; Magnani et al., 2005; Manera et al., 1999; Miccolis, 2000; Minuto et al., 2002a, 2002b; Sciortino, 2001). The mechanical properties of films and the effects on certain yield traits were also evaluated, as the soil temperature and its evapotranspiration (Magnani $e t$ al., 2005).

Depending on their use, biodegradable materials in Mater-Bi can be produced with different colours. Next to the traditional black film, experimental materials are green, brown or transparent, to obtain a beneficial application in certain conditions or for specific purposes, as it has been highlighted with coloured polyethylene film. The colouring of plastic materials for mulching has multiple purposes. In plant protection it can reduce the attacks of some phytophagous insects or virus vectors on vegetables and can control nematode attacks (Andino and 
Motsenbocker, 2004; Canale et al., 2005; Diaz-Perez et al., 2003, 2004; Fortnum et al., 1997; Magnani et al., 2003). Moreover, it is appropriate to increase the soil temperature near the plant, with a positive impact on the yield earliness, and to control weeds adequately (Magnani and Macchia, 1980). This must be related to the filtering of the solar radiation that still reaches the ground below the coloured film. In this regard, the films that seem to best raise the temperature of the soil and control weeds are the green ones (Magnani and Macchia, 1980; Johnson and Fennimore, 2005).

The purpose of this biennial research was precisely to check the effects of green biodegradable mulching on melon crop, compared to black biodegradable one. A black traditional polyethylene film was used as control. This research has also tried to solve a problem arisen with the use of biodegradable film on melon: the presence of black spots due to the waste plastics that remain attached to the peel. This fact, although do not invalidate the food characteristics, implies a significant decrease in external appearance quality of the product, with a negative reflection on marketing.

\section{Materials and Methods}

The research was conducted in 2004-2005, in open field, at the Center of S. Piero a Grado (lat. 43.67498, long. 10.34737), part of the Department of Crop Biology of the University of Pisa, Italy. The films tested in the experiments were as followed.

\section{First year (2004)}

- Experimental green biodegradable 'Cv104' (15 $\mu \mathrm{m}$ thick);

- Black biodegradable film 'Nf/803' (15 $\mu$ m thick);

- Black polyethylene LDPE (50 $\mu \mathrm{m}$ thick).

\section{Second year (2005)}

- Experimental green biodegradable 'Cv104' (15 $\mu \mathrm{m}$ thick);

- Black biodegradable film 'Nf/803' (15 $\mu \mathrm{m}$ thick);

- Experimental green biodegradable 'Cv205' (15 $\mu \mathrm{m}$ thick);

- Black polyethylene LDPE ( $50 \mu \mathrm{m}$ thick).

The two green biodegradable films had different properties related to the biodegradation rate, faster in film "Cv205", because of a different degree of Mater Bi polymer inside the film. The exact composition of the film can not be disclosed since covered by patent.

The physical characteristics of the soil were: skeleton $27 \mathrm{~g} \mathrm{~kg}^{-1}$; sand $590 \mathrm{~g} \mathrm{~kg}^{-1} ;$ silt $189 \mathrm{~g} \mathrm{~kg}^{-1}$; clay $221 \mathrm{~g} \mathrm{~kg}^{-1}$. Besides, the chemical composition was: $0,84 \mathrm{~g} \mathrm{~kg}^{-1}$ nitrogen $(\mathrm{N}), 12 \mathrm{~g} \mathrm{~kg}^{-1}$ phosphorous $\left(\mathrm{P}_{2} \mathrm{O}_{5}\right), 131$ $\mathrm{g} \mathrm{kg}^{-1}$ potassium $\left(\mathrm{K}_{2} \mathrm{O}\right)$.

Soil was plowed, milled and fertilized (100 kg/ha of 11:22:16 fertilizer, with a nutrient contribution of $120 \mathrm{~kg} / \mathrm{ha}$ of $\mathrm{N}, 80 \mathrm{~kg} / \mathrm{ha}$ of P205 and $180 \mathrm{~kg} / \mathrm{ha}$ of $\left.\mathrm{K}_{2} \mathrm{O}\right)$. After working the soil, the films ( $1.20 \mathrm{~m}$ width) were posed by a Checchi and Magli (Budrio, B0, Italy) machine on 11 May in the first year (2004), and on 5 May in the second one (2005). The following day, the melon (Cucumis melo L. var. reticulatus Naud.) seedlings were transplanted: cv Supermarket was used in both years. Plants were placed at a distance of $1 \mathrm{~m}$ along the row and $1.60 \mathrm{~m}$ between rows, for a total of 10 plants per parcel $\left(0.6\right.$ plants $\left./ \mathrm{m}^{2}\right)$. In each year a randomized block design with four replications was followed.

The cultivation practices were the ones usually applied to crop in both years, except to a pesticide treatment in June of first year for intense attack of aphids.

The measurements on the soil temperature at $10 \mathrm{~cm}$ depth started few days after transplantation and continued for about 20 days, after which the degradation of biodegradable materials did not allow a precise assessment of the effects of the biodegradable films on soil tem- peratures. Moreover, at that time plants were sufficiently developed and covered the mulching plots. These measurements were done using microchip sensors $\left(0.5^{\circ} \mathrm{C}\right.$ sensitivity), connected to a datalogger (mod. FT-2300/SE, Econorma, San Vendemiano, TV, Italy).

The degradation of the films was evaluated by visual observations, using a standard scoring prepared by Novamont technicians. The scale provided a rate score from 1 to $9(1=$ maximum degradation, $9=$ film intact). The evaluated parameters were: degradation of the covered and uncovered film; lesions and resistance to tearing.

The first year harvest was made four times, on $14^{\text {th }}, 18^{\text {th }}, 21^{\text {st }}$ and $27^{\text {th }}$ July, while the second year it was made three times, on $16^{\text {th }}, 23^{\text {rd }}$ and $18^{\text {th }}$ July.

The number and weight of fruits per plant and the number of fruits with biodegradable plastics residues on peel were detected; subsequently, the percentage of the stained fruits, both in number and weight, was calculated. At the last harvest, a representative sample of fruits was collected to check the quality through the determination of the following physical and chemical parameters: $\mathrm{pH}$ (by a $\mathrm{pH}$ meter), flesh firmness (measured by a penetrometer in the inner pulp of fruit cut transversely), titrable acidity (titration with $\mathrm{NaOH}$ and phenolphthalein), total soluble solids [by an optical refractometer, degrees Brix $\left.\left({ }^{\circ} \mathrm{Bx}\right)\right]$, electric conductivity (by a conductimeter), and percentage dry matter content.

Data were subjected to the ANOVA analysis and means were ranked by the Duncan's test.

\section{Results and Discussion}

\section{First year, 2004}

\section{Soil temperature}

Green biodegradable film (Cv104) determines the better increase of soil temperature, followed by LDPE film and biodegradable black (Figure 1). In particular, the gap between the green film and the two black films is greatest for the maximum temperatures (Figure 1a), especially in the first part of the cycle, since later on the degradation of the material tends to decrease the heat retention of this film. Considerable differences between blacks and green films were also registered for the minimum and average temperatures of the soil (Figure 1b,c), as we can expect because of the higher transmittance to solar radiation of the green film (Vox et al., 2005).

\section{Yield response}

Regardless of the colour of the film, plants grown on biodegradable mulching produced more fruits per plant, while there were no significant differences among theses for the yield weight. LDPE film shows a higher fruit mean weight (Table 1). These results agreed with previous researches conducted on melon and other vegetables such as cauliflower and tomato (Chiarini et al., 2008; Lopez et al., 2007; Magnani et al., 2005; Vetrano et al., 2009). Regarding the yield quality, the biodegradable films show positive effects in all the analysed parameters, except for titrable acidity (Table 2). In a season marked by a generally low production, due also to the attack of aphids already mentioned, the biodegradable film has achieved an increase of fruits number, while the traditional mulching shows larger fruits characterized, at the same time, by a lower dry matter content. This could be related to the amount of water available in the soil under the mulching film. The biodegradable films have higher soil evaporation (Magnani et al., 2005) than LDPE, and this lead to a lower accumulation of water in the fruit and to a positive effect on some quality parameters such as total soluble solids and titrable acidity as well to the aforementioned dry matter content. Other authors have found differences only for total sol- 
uble content (Gonzales et al., 2003), in relation to different genotypes and different climatic conditions.

The biodegradable films present a very small percentage of fruit with the presence of waste plastics on peel, and this rate did not differ significantly in relation to the colour of mulch or in comparison with the LDPE film (Table 2).

\section{Degradation of the films}

Green film degrades faster than black film (Figure 3). Twenty days from the first signs of degradation, the physical condition of the green film is compromised, while the black film maintains acceptable physical and mechanical properties for two months. The deterioration of the mechanical properties of Cv104 seems to affect only the soil temperatures, however when the development of the plant is already completed, thus not interfering with plant growth and production. On the other hand, the degradation of the innovative material is always an advantage compared to traditional film, in terms of environmental impact and reduction of labour costs. In fact, the biodegradable material disappears into soil 5-6 months after the end of the crop (Lopez et al., 2007).

\section{Second year, 2005}

\section{Soil temperature}

There are only small differences for minimum and mean temperature among the films. On the opposite, the maximum temperature shows the highest values under both the green films (Figure 3), confirming essentially the results obtained in the previous year.

\section{Yield response}

The green biodegradable films have led to good results, while a lower yield was obtained by the black biodegradable film, even lower than LDPE film (Table 3).

The commercial quality does not show significant differences among the for all the parameters, except for the percentage of waste plastics on the fruit. About this, the contact of the fruit peel with both the green biodegradable films causes a higher percentage of stained fruits, that differs statistically compared to Nf803 (Table 4).

\section{Degradation of the films}

Regarding the degradation of the covered side of the plastic (Figure 4), the green "CV 205" seems to be more resistant than the other two. These materials are sensitive to aging, especially for the covered part of the film (Figure 4). The mechanical properties of films "Nf803" and "Cv104" tend to decrease faster than "Cv 205", so these films are more susceptible to tearing and lesions (Figure 4).

Comparing these data with the percentage of fruit stained, it appears clear that green films stain the fruits more easily than black films. This phenomenon could be explained in these terms: the degradation occurring in all materials leads to a loss of mechanical properties and to the subsequent disintegration of the film. At the time of maximum development of fruits, just before harvest, while the black film is totally


(b)
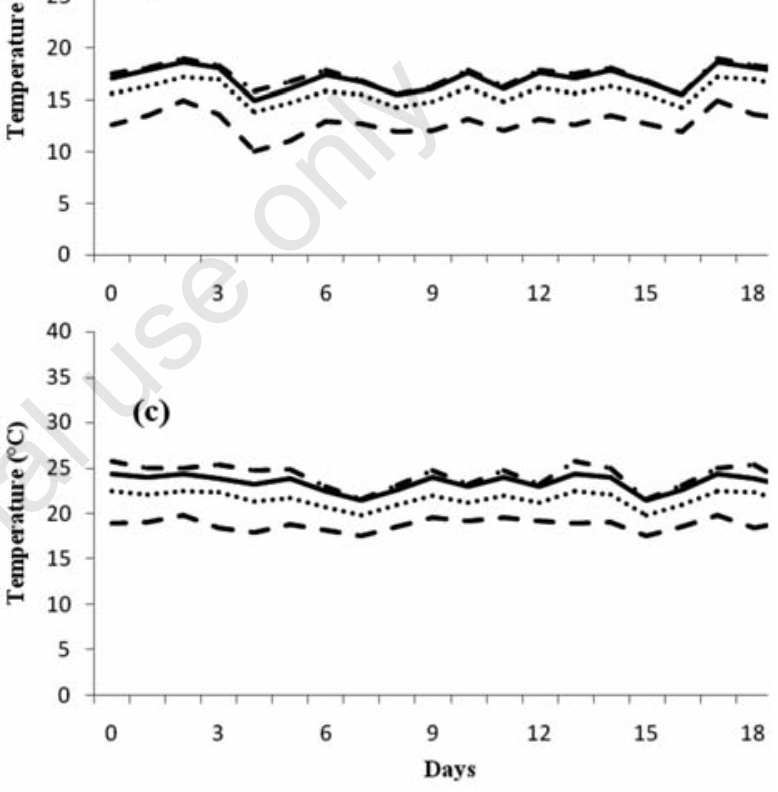

Figure 1. First year (2004). Course of maximum (a), minimum (b) and mean (c) temperature.

Table 1. First year (2004). Effect of mulching films on marketable yield of melon crop.

\begin{tabular}{|c|c|c|c|}
\hline \multirow{2}{*}{ Mulching films } & \multicolumn{3}{|c|}{ Yield } \\
\hline & & plant & $\begin{array}{l}\text { Fruit mean weight } \\
\qquad(\mathrm{g})\end{array}$ \\
\hline LDPE & $2.8^{b}$ & $3932.1^{\mathrm{a}}$ & $1404.3^{\mathrm{a}}$ \\
\hline Nf803/P & $3.6^{\mathrm{a}}$ & $3431.3^{\mathrm{a}}$ & $953.0^{\mathrm{b}}$ \\
\hline CV104 & $3.9^{\mathrm{a}}$ & $3509.2^{\mathrm{a}}$ & $899.7^{\mathrm{b}}$ \\
\hline
\end{tabular}

LDPE, low-density polyethylene; a,bvalues followed by different letters are significantly different at $\mathrm{P}=0.05$.

Table 2. First year (2004). Effect of mulching films on pulp quality of melon fruits.

\begin{tabular}{|c|c|c|c|c|c|c|}
\hline \multirow{3}{*}{ Mulching films } & \multirow{3}{*}{ Stained peel (\%) } & \multicolumn{4}{|c|}{ Fruit quality } & \multirow[b]{3}{*}{$\begin{array}{l}\text { Dry matter content } \\
\text { (\%) }\end{array}$} \\
\hline & & & & Pulp t & & \\
\hline & & $\mathrm{pH}$ & $\begin{array}{c}\text { Soluble solids } \\
\left.\text { ( }{ }^{\circ} \mathrm{Bx}\right)\end{array}$ & $\begin{array}{c}\text { Titrable acidity } \\
(\%)\end{array}$ & $\begin{array}{l}\text { Electric conductivity } \\
\left(\mathrm{dS} \mathrm{m}^{-1}\right)\end{array}$ & \\
\hline LDPE & $0.0^{\mathrm{a}}$ & $6.5^{b}$ & $10.8^{b}$ & $0.29^{\mathrm{a}}$ & $5.1^{\mathrm{b}}$ & $7.6^{\mathrm{b}}$ \\
\hline NF 803 & $7.3^{\mathrm{a}}$ & $6.9^{\mathrm{a}}$ & $14.4^{\mathrm{a}}$ & $0.14^{b}$ & $6.8^{\mathrm{a}}$ & $10.2^{\mathrm{a}}$ \\
\hline CV 104 & $5.7^{\mathrm{a}}$ & $6.8^{\mathrm{a}}$ & $15.5^{\mathrm{a}}$ & $0.12^{b}$ & $7.3^{\mathrm{a}}$ & $11.1^{\mathrm{a}}$ \\
\hline
\end{tabular}

${ }^{\circ} \mathrm{Bx}$, degrees Brix; LDPE, low-density polyethylene; ${ }^{\text {a, }}$ values followed by different letters are significantly different for $\mathrm{P}=0.05$. 

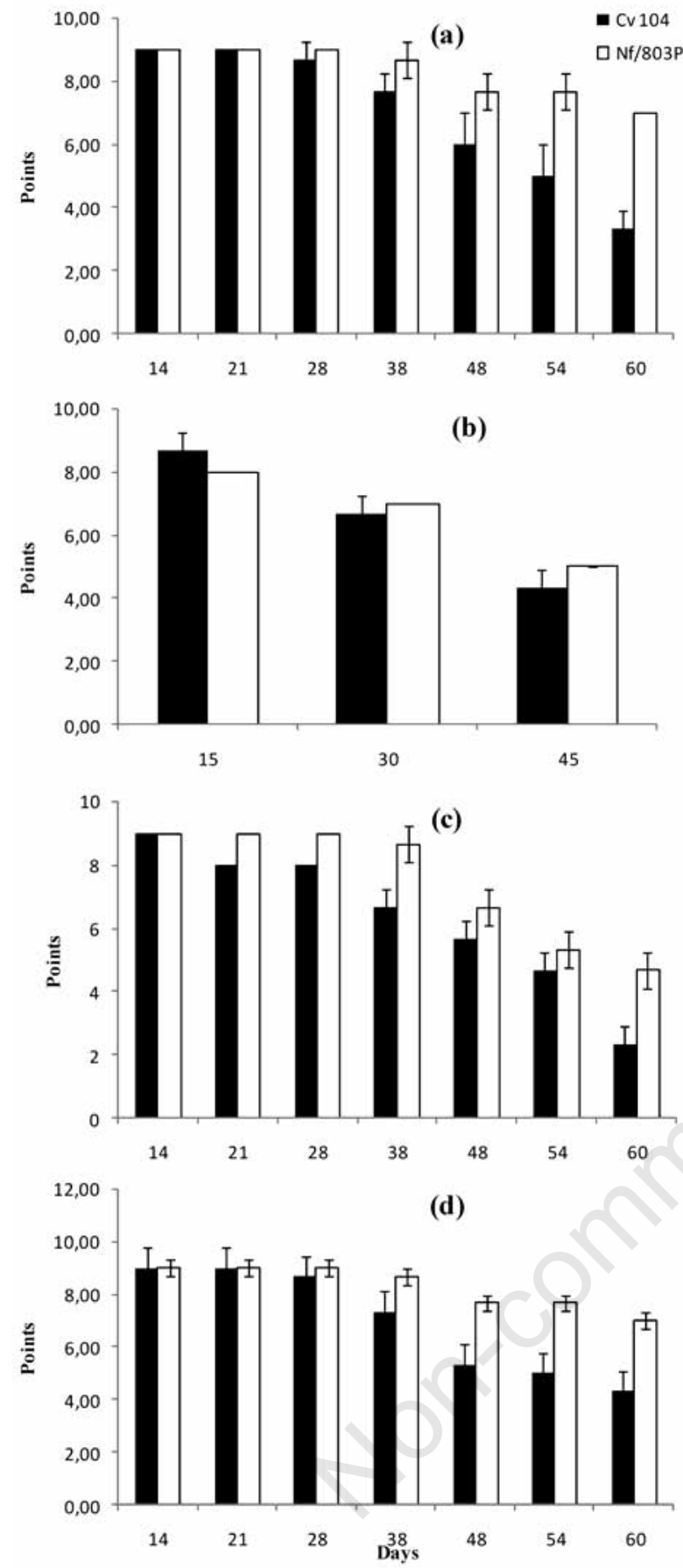

Figure 2. First year (2004). Degradation of biodegradable films.
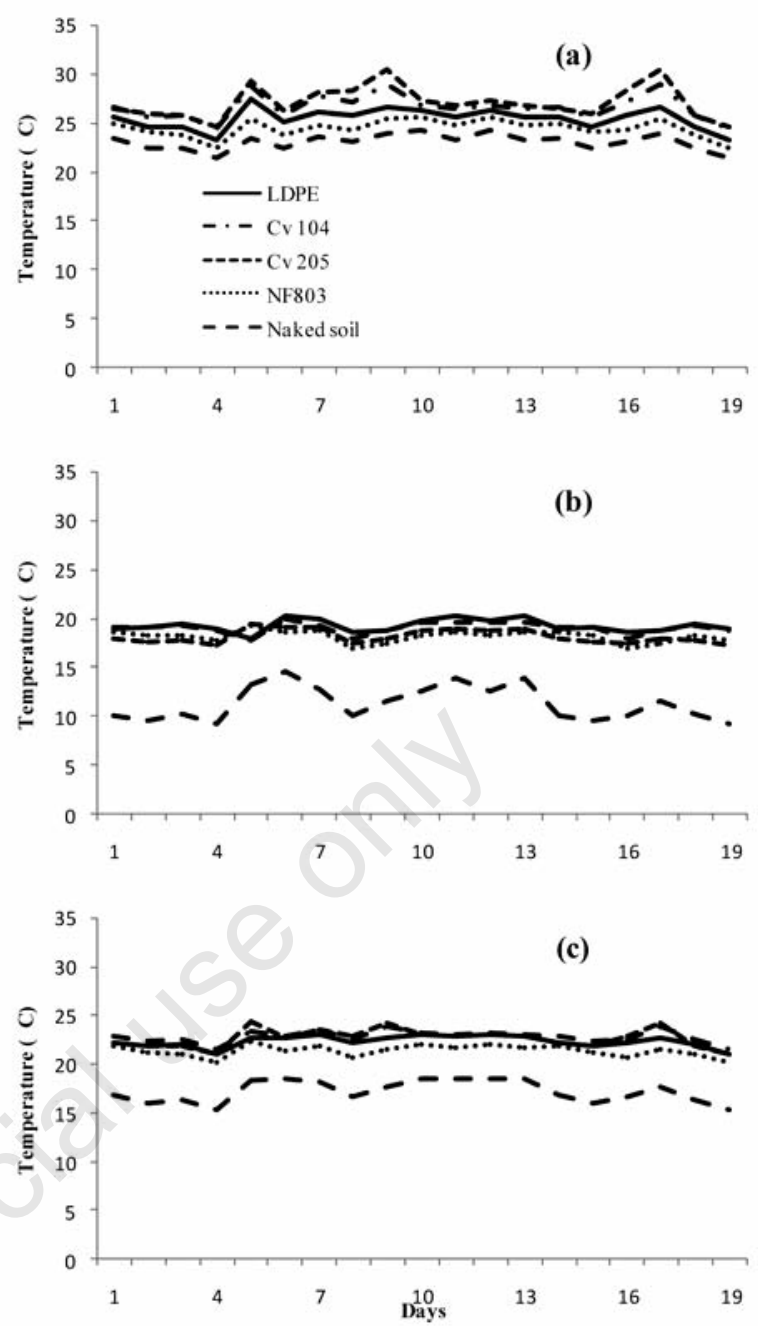

Figure 3. Second year (2005). Course of maximum (a), minimum (b) and mean (c) temperature.

Table 3. Second year (2005). Effect of mulching films on marketable yield of melon.

\begin{tabular}{|c|c|c|c|}
\hline \multirow[t]{2}{*}{ Mulching films } & \multicolumn{3}{|c|}{ Yield } \\
\hline & & $\begin{array}{r}\text { plant } \\
(\mathrm{g})\end{array}$ & $\begin{array}{l}\text { Fruit mean weight } \\
\text { (g) }\end{array}$ \\
\hline LDPE & $5.1^{\mathrm{ab}}$ & $5613.5^{\mathrm{ab}}$ & $1110.9^{a}$ \\
\hline NF 803 & $4.2^{b}$ & $4938.2^{\mathrm{b}}$ & $1224.4^{\mathrm{a}}$ \\
\hline CV104 & $6.4^{\mathrm{a}}$ & $7377.8^{a}$ & $1162.3^{\mathrm{a}}$ \\
\hline CV 205 & $6.5^{\mathrm{a}}$ & $7935.2^{\mathrm{a}}$ & $1222.2^{\mathrm{a}}$ \\
\hline
\end{tabular}

LDPE, low-density polyethylene; a,bvalues followed by different letters are significantly different at $\mathrm{P}=0.05$.

Table 4. Second year (2005). Effect of mulching films on pulp quality of melon fruits.

\begin{tabular}{|c|c|c|c|c|c|c|}
\hline \multirow{3}{*}{ Mulching films } & \multirow{3}{*}{ Stained peel (\%) } & \multicolumn{4}{|c|}{ Fruit quality } & \multirow[b]{3}{*}{$\begin{array}{c}\text { Dry matter content } \\
(\%)\end{array}$} \\
\hline & & & & Pulp tra & & \\
\hline & & $\mathrm{pH}$ & $\begin{array}{l}\text { Soluble solids } \\
\left.\text { ( }{ }^{\circ} \mathrm{Bx}\right)\end{array}$ & $\begin{array}{l}\text { Titrable acidity } \\
\text { (\%) }\end{array}$ & $\begin{array}{l}\text { Electric conductivity } \\
\left(\mathrm{dS} \mathrm{m}^{-1}\right)\end{array}$ & \\
\hline LDPE & $0.0^{c}$ & $6.6^{\mathrm{a}}$ & $9.1^{\mathrm{a}}$ & $0.15^{\mathrm{a}}$ & $6.1^{\mathrm{a}}$ & $9.1^{\mathrm{a}}$ \\
\hline NF 803 & $6.3^{\mathrm{b}}$ & $6.7^{\mathrm{a}}$ & $8.9^{\mathrm{a}}$ & $0.16^{\mathrm{a}}$ & $5.7^{\mathrm{a}}$ & $8.9^{\mathrm{a}}$ \\
\hline CV 104 & $17.9^{\mathrm{a}}$ & $6.7^{\mathrm{a}}$ & $9.4^{\mathrm{a}}$ & $0.19^{\mathrm{a}}$ & $5.8^{\mathrm{a}}$ & $9.4^{\mathrm{a}}$ \\
\hline CV 205 & $19.6^{\mathrm{a}}$ & $6.7^{\mathrm{a}}$ & $8.0^{\mathrm{a}}$ & $0.16^{\mathrm{a}}$ & $6.1^{\mathrm{a}}$ & $8.0^{\mathrm{a}}$ \\
\hline
\end{tabular}

${ }^{\circ} \mathrm{Bx}$, degrees Brix; LDPE, low-density polyethylene; a,b,cvalues followed by different letters are significantly different for $\mathrm{P}=0.05$. 

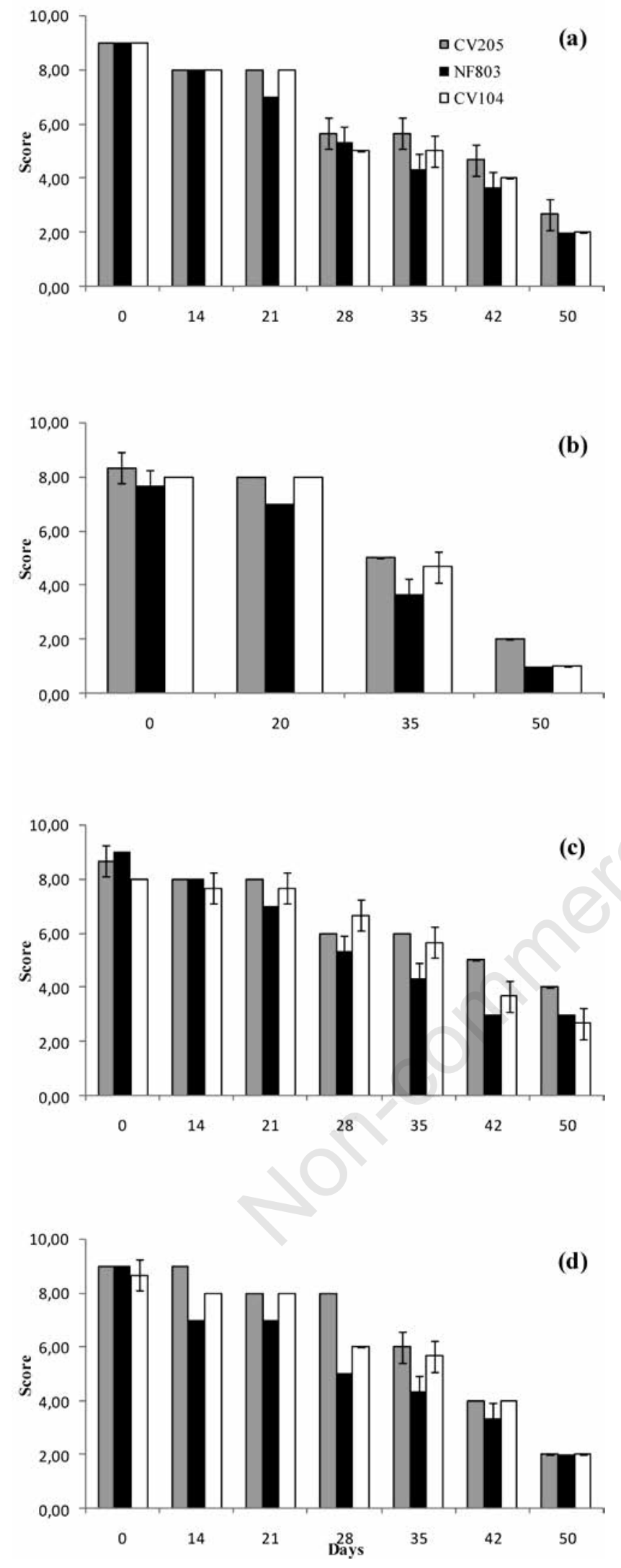

Figure 4. Second year (2005). Degradation of biodegradable films. degraded and its residues are too small to stain the skin, green films are still enough integral. However, its resistance to tearing (Figure 4) is reduced, so large pieces of film remain attached to the fruits peel.

\section{Conclusions}

From the results obtained in the trials the following guidelines can be drawn.

i) The green biodegradable films increase yield, both in the number and weight of fruits, since they improve the environmental conditions (soil temperature) of the cultivation. Moreover, green films show a better commercial quality than biodegradable black and LDPE film, especially for the sugar content and the degree of maturation.

ii) A further quality feature is represented by the presence of stains on fruits skin that affect the external quality of the product reducing its value. In the first year of the trial, the percentage of stained fruits was very low, regardless of the colour of the film, while in the second year the residues on melon peel of green films were higher than the black biodegradable mulch. This negative phenomenon could be probably related to the degree of degradation of the plastic underneath the fruit.

iii) Biodegradable materials allowed a good coverage of the soil during the entire crop cycle, ensuring an excellent mulching effect and self-degrading at the end of the cycle, in order to avoid the removal and disposal of plastic. The degradation is faster for the black polymer, maybe because of the higher temperature determined on plastic surface.

The use of biodegradable green film appeared definitely positive, as they merge the benefits of an innovative plastic materials, in terms of environmental impact, and those of the green-coloured film, which allows controlling weeds and improving plant growth and crop yield.

\section{References}

Andino J.R., Motsenbocker C.E., 2004. Coloured plastic mulches influence cucumber beetle populations, vine growth, and yield of watermelon. Hortscience 39:1246-1249.

Bastioli C., Facco S., Marini L., 1999. Mater-Bi starch-based materials: Present situation and future perspectives. pp 5-10 in Proc. Biodegradable Plastics Conf., Frankfurt, Germany.

Boldrin L., 1989. Utilisation de la feuille de paillage Ecopac. Plasticulture 83:51-52.

Brault D., Stewart K.A., Jenni S., 2002. Optical properties of paper and polyethylene mulches used for weed control in lettuce. Hortscience 37:87-91.

Canale A., Magnani G., Conti B., Filippi F., 2005. Pacciamatura colorata per il pomodoro: entomofauna ospite e caratteristiche della produzione. Colture Protette 11:85-91.

Candido V., Miccolis V., Gatta G., Margiotta S., Manera C., 2003. Innovative films for melon mulching in protected cultivation. Acta Hort. 614:379-386.

Caruso G., 1997. Studio sui film plastici di pacciamatura per la coltivazione della fragola nel Sud Italia. Riv. Frutticolt. Ortofloricolt. 59:79-83.

Chiarini F., Guerrini S., Mantoan C., Ranghino F., 2008. Biodegradable mulch a valid alternative to plastic. Inform. Agr. 64:47-51.

Davies D.H.K., Drysdale A., McKinlay R.J., Dent J.B., Williams G.H., 1993. Novel approaches to mulches for weed control in vegetables. pp 271-276 in Proc. Conf. on crop protection in Northern Britain, Dundee, UK.

Degli Innocenti G., Tosin M., Bellia G,. 2000. Degradability of plastics. 
Standard methods developed in Italy. pp 115-121 in Proc. Int. Conf. on Biodegradable Polymers: production, marketing, utilisation and residues management, Wolfsburg, Germany.

Diaz-Perez J.C., Batal K.D., Granberry D., Bertrand D., Giddings D., Pappu H., 2003. Growth and yield of tomato on plastic film mulches as affected by tomato spotted wilt virus. Hortscience 38:395-399.

Diaz-Perez J.C., Granberry D., Bertrand D., Giddings D., 2004. Tomato plant growth during establishment as affected by root zone temperature under coloured mulches. Acta Hort. 631:119-124.

Flechaire M., 1991. Mater-Bi: un materiel thermoplastique biodegradable a base d'amidon. pp 98-101 in Proc. Conf. Valorisation industrielle non alimentaire des productions de grande culture, Paris, France.

Fortnum B.A., Decoteau D.R., Kasperbauer M.J., 1997. Coloured mulches affect yield of fresh-market tomato infected with Meloidogyne incognita. J. Nematol. 29: 538-546.

González A., Fernández J.A., Martín P., Rodríguez R., López J., Bañón S., Franco J.A., 2003. Behaviour of biodegradable film for mulching in open-air melon cultivation in South-East Spain. KTBL-Schrift 71-77.

Johnson M.S., Fennimore S.A., 2005. Weed and crop response to coloured plastic mulches in strawberry production. Hortscience 40:1371-1375.

López J., González A., Fernández J.A., Bañón S., 2007. Behaviour of biodegradable films used for mulching in melon cultivation. Acta Hortic. 747:125-130.

Magnani G., Filippi F., Graifenberg A., Bertolacci M., 2005. Valutazione agronomica di film biodegradabili per la pacciamatura. Colture Protette 1:49-68.

Magnani G., Graifenberg A., Filippi F., Marroni E., 2003. Pacciamatura colorata e tessuto non tessuto per lo zucchino in pien'aria. Colture Protette 8:51-56.

Magnani G., Macchia M., 1980. Valutazione agronomica di alcuni tipi di materiali plastici per pacciamatura. Colture Protette 4:23-32.

Manera C. Margiotta S., Picuno P., 1999. Film plastici innovativi e biodegradabili per le colture protette. Colture Protette 28:59-64.

Mazollier C., 2001. Paillages biodégradables en maraichage. PHM Revue Horticole 42:16-20.

Miccolis V., 2000. Impiego di film plastici innovativi per la pacciamatura e la solarizzazione del terreno in ambiente protetto. Atti Convegno "Impiego in agricoltura di plastiche innovative biodegradabili per la solarizzazione del terreno", Matera, Italy, pp 21-27.

Minuto G., Bruzzone C., Guerrini S., Farachi F., Garibaldi A., 2002a. Lotta alle malerbe in orticoltura con pacciamatura biodegradabile. Informatore Fitopatologico. La difesa delle piante 52:24-30.

Minuto G., Frumento A., Versari M., Farachi F., Garibaldi A., 2002b. Impiego della pacciamatura con film biodegradabili per la lotta alle malerbe in orticoltura. Atti "Incontri Fitoiatrici", Grugliasco, T0, Italy, pp 121:125.

Olsen J.K., Gounder R.K., 2001. Alternatives to polyethylene mulch film, a field assessment of transported materials in capsicum (Capsicum annuum L.). Aust. J. Exp. Agr. 41:93-103.

Quezada Rosano M.R., Sànchez S., Munguia J., Quiroz M., 1994. Evaluation of photodegradable mulch films for the cultivation of tomato crops. pp 181-186 in Proc. 25th Nat. Agricultural Plastics Congress. Lexington, KY, USA.

Sciortino A., 2001. Pacciamatura, a quali condizioni? Colture Protette 30:39-43.

Vetrano F., Fascella S., Iapichino G., Incalcaterra G., Girgenti P., Sutera P., Buscemi G., 2008. Response of melon genotypes to polyethylene and biodegradable starch-based mulching films used for fruit production in the western coast of Sicily. Acta Hortic. (ISHS) 807:109114.

Vidril V., 2001. Paillages biodégradables en espace verts. PHM Revue Horticole 421:21-27.

Vox G., Schettini E., Scarascia-Mugnozza G., 2005. Radiometric properties of biodegradable films for horticultural protected cultivation. Acta Hortic. 691:575-582. 